Vol. 4: 363-375.

\title{
Leaching and uptake of nitrogen and phosphorus from cow slurry and fox manure in a lysimeter trial
}

\author{
Erkki Kemppainen \\ Agricultural Research Centre of Finland, FIN-31600 Jokioinen, Finland
}

\begin{abstract}
The effects of soil type, spreading time and use of a nitrification inhibitor (Didin) on the leaching and uptake of nitrogen and phosphorus from cow slurry and fox manure were studied in a lysimeter trial during 1989-1992.

The runoff volume and leaching of total nitrogen in peat soil were double those in fine sand soil. There was no essential difference in the leaching of nitrate nitrogen, but the amount of ammonium nitrogen leached from peat soil was 50 -fold and that of organic nitrogen about 3 -fold the amounts leached from fine sand soil. The amount of total phosphorus leached from peat soil was 23 -fold and that of soluble phosphorus 39 -fold the amounts leached from fine sand soil.

There were only minor differences between cow slurry and fox manure in the leaching of nitrogen. The least nitrogen was leached after manure application in May. Didin did not have any significant effect. In peat soil, significantly more phosphorus leached from fox manure than from cow slurry. Spreading time had no effect on phosphorus leaching.

Considerably higher barley grain yields were harvested from peat soil than from fine sand soil. Fox manure proved to be a much more effective fertilizer than cow slurry. In the first experimental year, December spreading resulted in a lower yield than other spreading times. Of the total nitrogen applied in manure, $24-41 \%$ was recovered in barley yield (grain+straw) and $4-21 \%$ in runoff; the figures for phosphorus were $6-51 \%$ and $0-2.6 \%$, respectively.
\end{abstract}

Key words: peat soil, fine sand soil, spreading time, nitrification, nitrification inhibitor, nitrate, ammonium, organic nitrogen, soluble phosphorus, runoff

\section{Introduction}

The leaching of nutrients from livestock manures has been studied rather little in Finland. Yet results published by Melanen et al. (1985) and Niinioja (1993) indicate that the use of livestock manure can result in considerable nutrient leach- ing. The same has been suggested in many reports published elsewhere (e.g. Brink et al. 1979, Vetter and Steffens 1981, Brink and Jernlås 1982, Herrmann et al. 1983).

Many farms produce excessive amounts of livestock manure in relation to their field area. Another reason for excessive manuring may be that farmers do not know the fertilizer value of 
Kemppainen, E.: Leaching and uptake of nitrogen and phosphorus...

manure. Owing to insufficient storage capacity, about one-third of the manure produced in Finland has to be spread in autumn and some in winter.

One way in which the hazards of nitrogen leaching have been overcome is by preventing the oxidation of manure ammonia with nitrification inhibitors. The use of inhibitors in combination with manure application in autumn has given rather good results. However, the profitability of inhibitor use is still unclear (Amberger 1981, Kjellerup 1986, Pain et al. 1987, Görlitz et al. 1988, Kemppainen 1989a, Tveitnes and Håland 1989, Görlitz 1990, Meissner et al. 1991, Nilsson 1991).

Not only manure nitrogen but also manure phosphorus poses a threat to the environment when leached from fields. The phosphorus content of even a moderate dose of manure may often be too high for a crop. Moreover, manure phosphorus is more mobile in soil and thus more susceptible to leaching than the phosphorus in mineral fertilizer (Vetter and Steffens 1981).

German studies show that acid peat soils are susceptible to phosphorus leaching (Scheffer et al. 1981, Vetter and Steffens 1981). Very high amounts of phosphorus can leach through a peat soil when manure is applied in large quantities (Scheffer et al. 1981, Bartels and Scheffer 1987). The risk of phosphorus leaching from acid peat soils appears to have been overlooked in Finland even though peat fields account for over $20 \%$ of the arable area.

Fur animal manure is particularly problematic for environmental protection, as manures of mink and fox contain about 10 times more nitrogen and 30 times more phosphorus than cow slurry (Kemppainen 1984). Thus fur animal manures often cause considerable environmental problems on farms (Pedersen 1991). Owing to the high nutrient content of the manures it is very difficult to spread them at rates low enough to avoid overfertilization. Moreover, many fur animal farms have too small an arable area for manure spreading.

This study compares the leaching and uptake of nitrogen and phosphorus from two different manures: cow slurry and fox manure. Cow slurry was chosen because it is an important type of manure on Finnish farms, and fox manure because of its widespread use in eastern Finland and Ostrobothnia. Only a few studies on the fertilizer value and environmental impacts of fox manure, a very concentrated type of manure, have been published. Two soil types typical of northern Finland were chosen for the experiment: Carex peat and fine sand. The effects of spreading time and use of a nitrification inhibitor were also studied.

\section{Material and methods}

A lysimeter field with 66 small lysimeters (illustrated in Fig. 1) was set up at the Agricultural Research Centre of Finland, Kainuu Research Station, Sotkamo ( $\left.64^{\circ} 06^{\prime} \mathrm{N}, 28^{\circ} 20^{\prime} \mathrm{E}\right)$ in summer 1989. All the lysimeters are monoliths. Half of them were filled with cultivated fine sand soil and half with Carex peat soil (Table 1). The treatments used in the experiment are given in Table 2. There were three replicates.

Before the experiment was set up, the lysimeter soils were all turned (ploughed) to a depth of $10 \mathrm{~cm}$. Manures applied to lysimeter soils in September were harrowed into the soil about three hours after spreading. In December, the manures were spread on a 3-4-cm-thick snow cover. In May, they were first spread on lysimeter soils which had been harrowed to a depth of $10 \mathrm{~cm}$ and were then harrowed into the soil three days after application. The nutrient content of manures and the amounts of nutrients applied to the lysimeter soils are presented in Table 3. Manure samples were analysed according to Kemppainen (1989b).

Spring barley (Hordeum vulgare var. Arra, 500 germinating seeds $/ \mathrm{m}^{2}$ ) was grown in lysimeters during 1990-1992. During 1991 and 1992, the residual effects of different treatments were studied and the lysimeters were fertilized equally with mineral fertilizer (N-P-K $=85-30$ $60 \mathrm{~kg} / \mathrm{ha})$. 
Vol. 4: 363-375.

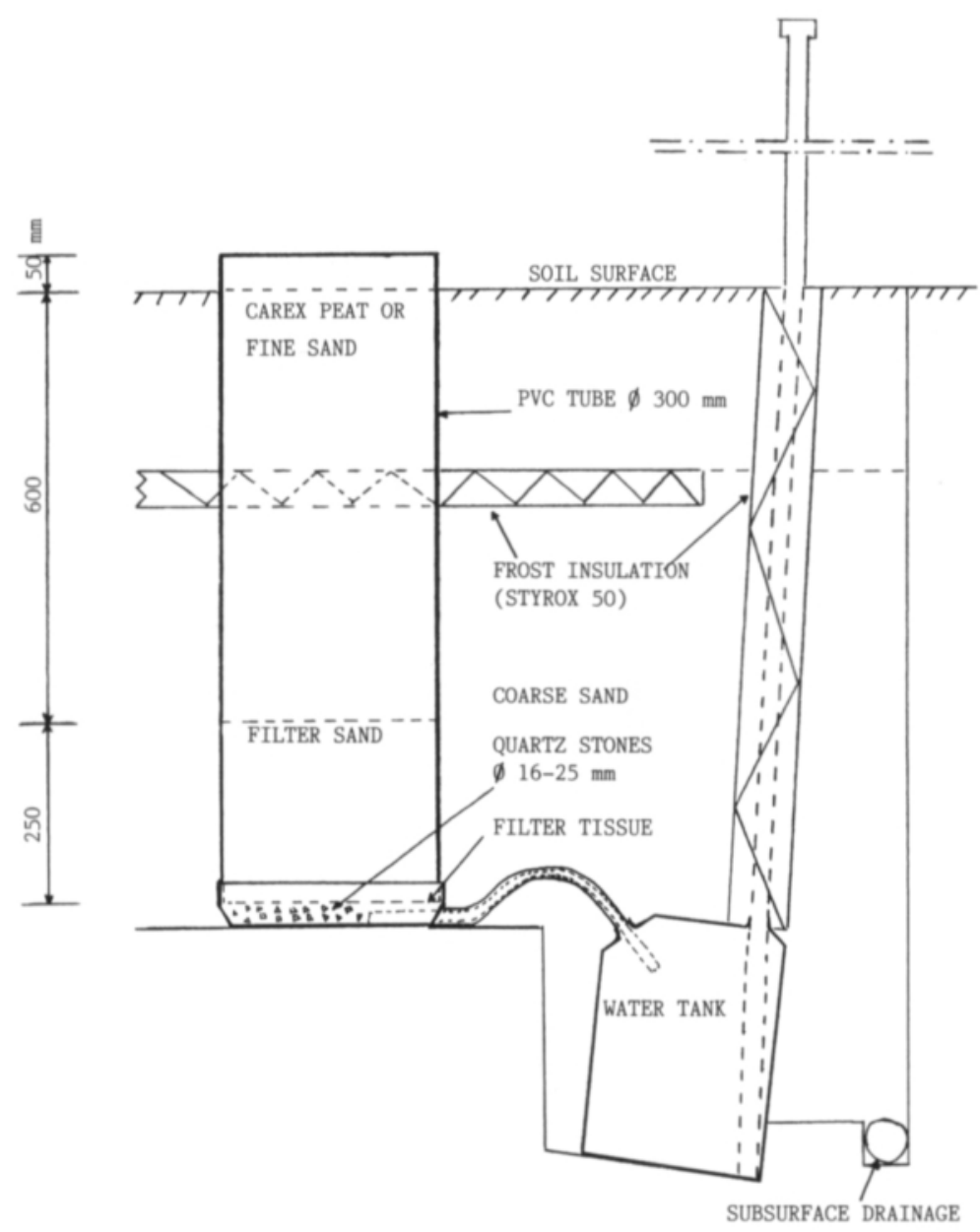

Fig. 1. Diagram of a lysimeter.

Water tanks were emptied and water samples taken from the lysimeters 13 times. The amount of water was measured by weighing. Total nitrogen, nitrate nitrogen, ammonium nitrogen, total phosphorus and soluble phosphorus contents were analysed as required by Finnish standards (SFS 3031, SFS 3030, SFS 3032 and SFS 3026). Phosphorus was analysed on sam-

Table 1. Chemical properties of experimental soils. Nutrients were determined according to Vuorinen and Mäkitie (1955), and $\mathrm{pH}$ from a mixture of soil/deionized water = 1/2.5.

\begin{tabular}{lrrrrr}
\hline Soil type & $\mathrm{pH}$ & \multicolumn{3}{c}{$\mathrm{mg} / \mathrm{l}$} \\
\cline { 3 - 6 } & & $\mathrm{Ca}$ & $\mathrm{K}$ & $\mathrm{Mg}$ & $\mathrm{P}$ \\
\hline Fine sand soil & 6.3 & 1170 & 110 & 79 & 10.4 \\
Carex peat soil & 5.0 & 800 & 43 & 239 & 3.0 \\
\hline
\end{tabular}




\section{AGRICULTURAL SCIENCE IN FINLAND}

Kemppainen, E.: Leaching and uptake of nitrogen and phosphorus...

Table 2. Treatments of various lysimeters.

\begin{tabular}{|c|c|c|c|c|}
\hline $\begin{array}{l}\text { Soil } \\
\text { type }\end{array}$ & $\begin{array}{l}\text { Manure } \\
\text { type }\end{array}$ & $\begin{array}{l}\text { Manure } \\
\text { rate }\end{array}$ & $\begin{array}{l}\text { Spreading/ } \\
\text { treatment }\end{array}$ & Spreading date \\
\hline $\begin{array}{l}\text { Carex } \\
\text { peat } \\
" \\
"\end{array}$ & $\begin{array}{l}\text { Cow } \\
\text { slurry } \\
" \\
"\end{array}$ & $\begin{array}{l}48 \text { t/ha } \\
" \\
" \\
"\end{array}$ & $\begin{array}{l}\text { September } \\
"+\text { Didin }(15 \mathrm{~kg} / \mathrm{ha}) \\
\text { December } \\
\text { May }\end{array}$ & $\begin{array}{l}26.09 .1989 \\
26.09 .1989 \\
19.12 .1989 \\
11.05 .1990\end{array}$ \\
\hline $\begin{array}{l}" \\
" \\
"\end{array}$ & $\begin{array}{l}\text { Fox } \\
\text { manure } \\
" \\
"\end{array}$ & $\begin{array}{l}23 \text { tha } \\
" \\
" \\
"\end{array}$ & $\begin{array}{l}\text { September } \\
"+\text { Didin }(15 \mathrm{~kg} / \mathrm{ha}) \\
\text { December } \\
\text { May }\end{array}$ & $\begin{array}{l}26.09 .1989 \\
26.09 .1989 \\
19.12 .1989 \\
11.05 .1990\end{array}$ \\
\hline $\begin{array}{l}\text { Fine } \\
\text { sand } \\
" \\
"\end{array}$ & $\begin{array}{l}\text { Cow } \\
\text { slurry } \\
" \\
"\end{array}$ & $\begin{array}{l}48 \text { tha } \\
" \\
" \\
"\end{array}$ & $\begin{array}{l}\text { September } \\
"+\text { Didin }(15 \mathrm{~kg} / \mathrm{ha}) \\
\text { December } \\
\text { May }\end{array}$ & $\begin{array}{l}26.09 .1989 \\
26.09 .1989 \\
19.12 .1989 \\
11.05 .1990\end{array}$ \\
\hline $\begin{array}{l}" \\
" \\
"\end{array}$ & $\begin{array}{l}\text { Fox } \\
\text { manure } \\
" \\
"\end{array}$ & $\begin{array}{l}23 \text { tha } \\
" \\
" \\
"\end{array}$ & $\begin{array}{l}\text { September } \\
"+\text { Didin }(15 \mathrm{~kg} / \mathrm{ha}) \\
\text { December } \\
\text { May }\end{array}$ & $\begin{array}{l}26.09 .1989 \\
26.09 .1989 \\
19.12 .1989 \\
11.05 .1990\end{array}$ \\
\hline $\begin{array}{l}\text { Carex } \\
\text { peat }\end{array}$ & $\begin{array}{l}\text { Unfert. } \\
\text { NPK }\end{array}$ & 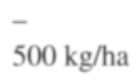 & May & $\begin{array}{c}- \\
14.05 .1990\end{array}$ \\
\hline $\begin{array}{l}\text { Fine } \\
\text { sand }\end{array}$ & $\begin{array}{l}\text { Unfert. } \\
\text { NPK }\end{array}$ & $\begin{array}{l}- \\
500 \mathrm{~kg} / \mathrm{ha}\end{array}$ & $\overline{-}$ & $\frac{-}{14.05 .1990}$ \\
\hline
\end{tabular}

ples conserved with sulphuric acid. The amount of organic nitrogen was calculated by subtracting nitrate and ammonium nitrogen from the amount of total nitrogen. Combined results for the whole experimental period are mostly presented. In some cases, however, results for shorter leaching periods are given as follows:

$$
\begin{array}{ll}
\text { period I } & 26.09 .1989-09.05 .1990 \\
\text { period II } & 10.05 .1990-28.05 .1991 \\
\text { period III } 29.05 .1991-15.05 .1992 \\
\text { period IV } 16.05 .1992-05.11 .1992
\end{array}
$$

The majority of the lysimeters functioned well; a few had to be discarded owing to exceptionally small runoff. The results for unfertilized peat are based on only two replicates and those for unfertilized fine sand on one lysimeter.

In addition to nutrient leaching, grain and straw yields were measured and their nitrogen and phosphorus contents analysed according to Kähäri and Nissinen (1978). Nitrogen and phosphorus uptake was calculated. The proportion of manure nitrogen and phosphorus in the yield and runoff was calculated by first subtracting the

Table 3. Nutrient content of different manure types ( $\mathrm{g} / \mathrm{kg}$, on fresh weight basis) and amounts of nutrients applied to lysimeter soils $(\mathrm{kg} / \mathrm{ha})$.

\begin{tabular}{lcccccc}
\hline Nutrient & \multicolumn{2}{c}{$\mathrm{g} / \mathrm{kg}$} & & \multicolumn{3}{c}{$\mathrm{kg} / \mathrm{ha}$} \\
\cline { 2 - 3 } \cline { 6 - 7 } & Cow & Fox & & Cow & Fox & NPK \\
\hline Total N & 3.47 & 24.55 & & 167 & 565 & 85 \\
Soluble N & 2.15 & 14.32 & & 103 & 329 & 85 \\
Total P & 0.72 & 29.50 & & 35 & 679 & 30 \\
Total K & 3.63 & 9.27 & & 174 & 213 & 60 \\
\hline
\end{tabular}


Vol. 4: 363-375.

amounts of $\mathrm{N}$ and $\mathrm{P}$ in the corresponding unfertilized treatments.

The experiment was set up and the results were calculated according to the split-split-plot design. The main plots consisted of two soil types, subplots of two manure types, and subsubplots of four spreading treatments. In some cases, one-way variance analyses were also applied. A VAX 11/780 computer and SAS program were used for the calculations (SAS Institute 1985).

\section{Results}

\section{Runoff}

Throughout the experimental period significantly more water percolated through manure-treated peat soil than through fine sand soil (Table 4), the percolation level corresponding to $49 \%$ and $24 \%$ of precipitation, respectively. Runoff was exceptionally high during the third leaching period (Fig. 2). The figure also shows that the difference between soil types increased steadily as the experiment proceeded.

Less water percolated through lysimeter soils fertilized with fox manure than through those fertilized with cow slurry. There always seemed to be less runoff water from lysimeters manured in May than from other spreading treatments. Runoff from control treatments was of the same order as from lysimeters fertilized with livestock manure. However, there was substantially less runoff from unfertilized peat than from other peat soils.

\section{Leaching of nitrogen}

More ammonium $\mathrm{N}$, organic $\mathrm{N}$ and total $\mathrm{N}$ leached from manure-treated peat soil than from fine sand soil (Table 5). One-way variance analysis showed that the difference in the leaching of total $\mathrm{N}$ was statistically significant $(\mathrm{HSD}=$

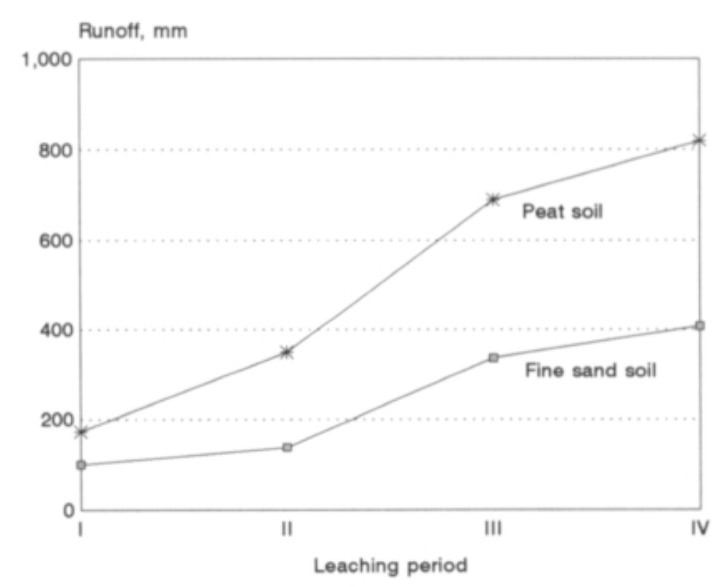

Fig. 2. Cumulative runoff from manure-treated peat and fine sand soil lysimeters.

$11.5 \mathrm{~kg} / \mathrm{ha})$. The most striking difference was in the leaching of ammonium $\mathrm{N}$ : about 50 times more ammonium $\mathrm{N}$ leached from peat soil than from fine sand soil. However, there was no sig-

Table 4. Runoff from lysimeters. Averages for soil types, manure types and spreading times, and figures for control treatments.

\begin{tabular}{lcc}
\hline Treatment & $\begin{array}{c}\text { Number of } \\
\text { lysimeters }\end{array}$ & Runoff, mm \\
\hline Peat soil & 24 & 820 \\
Fine sand soil & 24 & 406 \\
HSD (P =0.05) & & 322 \\
Cow slurry & 24 & 671 \\
Fox manure & 24 & 555 \\
HSD (P = 0.05) & & 97 \\
September & 12 & 678 \\
September+Didin & 12 & 667 \\
December & 12 & 618 \\
May & 12 & 490 \\
HSD $(P=0.05)$ & & 160 \\
No significant interactions & & \\
\hline Peat $\quad$ Unfert. & 2 & 294 \\
" NPK & 3 & 784 \\
Fine $\quad$ Unfert. & 1 & 528 \\
sand $\quad$ NPK & 3 & 370 \\
\hline
\end{tabular}


Kemppainen, E.: Leaching and uptake of nitrogen and phosphorus...



\section{$\square$ Organic N $\square$ Ammonium N \\ Nitrate $\mathrm{N}$}

Fig. 3. Proportion of organic, ammonium and nitrate nitrogen relative to total nitrogen in runoff from manure-treated lysimeters during various leaching periods. nificant difference in the leaching of nitrate $\mathrm{N}$. The proportion of total nitrogen that was nitrate nitrogen in percolated water increased in the course of the experiment in both soil types (Fig. 3). In peat soil, the proportion of ammonium nitrogen remained significant towards the end of the experiment whereas in fine sand soil it was low throughout.

As a whole, manure type had no effect on the leaching of the various nitrogen fractions. However, in peat soil slightly more total $\mathrm{N}$, nitrate $\mathrm{N}$ and ammonium $\mathrm{N}$ seemed to leach from fox manure than from cow slurry but in fine sand soil the situation was reversed. Leaching of all nitrogen fractions was lowest in spring-applied manure. For ammonium nitrogen, however, this was true only in peat soil. In fine sand soil, leaching of ammonium nitrogen was negligible (0.3$0.4 \mathrm{~kg} / \mathrm{ha}$ ) at all spreading times. Didin did not decrease nitrogen leaching. Manure spreading time exerted an influence throughout the experimental period (Fig. 4).

Table 5. Leaching of nitrate, ammonium, organic and total nitrogen. Averages for soil types, manure types and spreading times, and figures for control treatments.

\begin{tabular}{|c|c|c|c|c|c|}
\hline \multicolumn{2}{|c|}{ Treatment } & $\begin{array}{c}\mathrm{NO}_{3}-\mathrm{N} \\
\mathrm{kg} / \mathrm{ha}\end{array}$ & $\begin{array}{c}\mathrm{NH}_{4}-\mathrm{N} \\
\mathrm{kg} / \mathrm{ha}\end{array}$ & $\begin{array}{l}\text { Org.N } \\
\mathrm{kg} / \mathrm{ha}\end{array}$ & $\begin{array}{l}\text { Tot.N } \\
\mathrm{kg} / \mathrm{ha}\end{array}$ \\
\hline \multicolumn{2}{|c|}{ Peat soil } & 33.8 & 15.2 & 19.9 & 68.8 \\
\hline \multicolumn{2}{|c|}{ Fine sand soil } & 27.9 & 0.3 & 6.9 & 35.2 \\
\hline \multicolumn{2}{|c|}{$\operatorname{HSD}(\mathrm{P}=0.05)$} & 50.1 & 3.8 & 5.6 & 47.9 \\
\hline \multicolumn{2}{|c|}{ Cow slurry } & 32.5 & 7.1 & 14.2 & 53.9 \\
\hline \multicolumn{2}{|c|}{ Fox manure } & 29.2 & 8.4 & 12.5 & 50.1 \\
\hline \multicolumn{2}{|c|}{$\operatorname{HSD}(P=0.05)$} & 6.7 & 1.4 & 2.9 & 7.0 \\
\hline \multicolumn{2}{|c|}{ September } & 35.4 & 9.1 & 15.0 & 59.6 \\
\hline \multicolumn{2}{|c|}{ September+Didin } & 33.3 & 9.1 & 15.5 & 57.9 \\
\hline \multicolumn{2}{|c|}{ December } & 33.0 & 8.3 & 13.5 & 54.8 \\
\hline \multicolumn{2}{|l|}{ May } & 21.6 & 4.5 & 9.5 & 35.6 \\
\hline \multicolumn{2}{|c|}{$\operatorname{HSD}(\mathrm{P}=0.05)$} & 14.8 & 3.9 & 4.9 & 18.6 \\
\hline \multicolumn{2}{|c|}{$\begin{array}{l}\text { Significant interacti } \\
\text { - soil } x \text { manure } \\
\text { - soil } x \text { spreading } \\
\end{array}$} & * & $\begin{array}{c}* \\
* *\end{array}$ & & * \\
\hline Peat & Unfert. & 10.0 & 3.4 & 6.5 & 19.9 \\
\hline & NPK & 28.5 & 12.9 & 13.3 & 54.6 \\
\hline Fine & Unfert. & 15.1 & 0.2 & 3.6 & 18.8 \\
\hline sand & NPK & 14.9 & 0.3 & 3.8 & 19.0 \\
\hline
\end{tabular}


Vol. 4: 363-375.

Nitrogen leached, $\mathrm{kg} / \mathrm{ha}$



Fig. 4. Cumulative leaching of total nitrogen from unfertilized lysimeters and from those manured in September and in May.

\section{Leaching of phosphorus}

The amount of total phosphorus leached from manure-treated peat soil was 23 times that from fine sand soil (Table 6). The difference in the leaching of soluble phosphorus was 39 -fold.

According to one-way variance analysis, the differences were statistically significant (HSD for total $\mathrm{P}=979 \mathrm{~g} / \mathrm{ha}$, for soluble $\mathrm{P}=899 \mathrm{~g} / \mathrm{ha}$ ). The highest single figure, $4609 \mathrm{~g}$ total $\mathrm{P} / \mathrm{ha}$, was for fox manure applied to peat soil in December.

Leaching of phosphorus from peat soil was considerably higher during the latter two leaching periods than during the former two (Fig. 5). The figure also shows that the differences between soil and manure types increased towards the end of the experiment. More phosphorus leached from fox manure than from cow slurry (Table 6). For total phosphorus, however, this was true only in peat soil. In fine sand soil, leaching of total P was very low (about $100 \mathrm{~g} / \mathrm{ha}$ ) and not connected with manure type. No differences were found between spreading times.

\section{Barley grain yields}

Higher grain yields were always harvested from peat soil than from fine sand soil (Table 7). One-

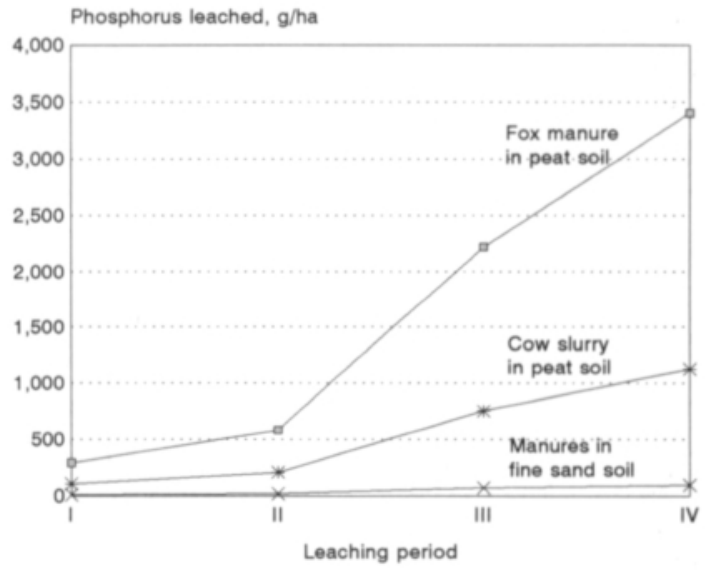

Fig. 5. Cumulative leaching of total phosphorus from fox manure in peat soil, cow slurry in peat soil and manures in fine sand soil.

way variance analysis demonstrated that the differences were statistically significant in 1991 $(\mathrm{HSD}=660 \mathrm{~kg} / \mathrm{ha})$ and in $1992(\mathrm{HSD}=410 \mathrm{~kg} /$ ha). Fox manure invariably produced higher grain yields than cow slurry. In the last experimental year, the advantage gained by fox ma-

Table 6. Leaching of total and soluble phosphorus. Averages for soil types, manure types and spreading times, and figures for control treatments.

\begin{tabular}{|c|c|c|c|}
\hline \multicolumn{2}{|c|}{ Treatment } & $\begin{array}{l}\text { Total P } \\
\mathrm{g} / \mathrm{ha}\end{array}$ & $\begin{array}{c}\text { Soluble P } \\
\text { g/ha }\end{array}$ \\
\hline \multicolumn{2}{|c|}{ Peat soil } & 2264 & 1848 \\
\hline \multicolumn{2}{|c|}{ Fine sand soil } & 99 & 47 \\
\hline \multicolumn{2}{|c|}{ HSD $(P=0.05)$} & 2271 & 2102 \\
\hline \multicolumn{2}{|c|}{ Cow slurry } & 611 & 437 \\
\hline \multicolumn{2}{|c|}{ Fox manure } & 1752 & 1457 \\
\hline \multicolumn{2}{|c|}{ HSD $(P=0.05)$} & 1098 & 1042 \\
\hline \multicolumn{2}{|c|}{ September } & 1142 & 897 \\
\hline \multicolumn{2}{|c|}{ September+Didin } & 779 & 570 \\
\hline \multicolumn{2}{|c|}{ December } & 1567 & 1275 \\
\hline \multicolumn{2}{|c|}{ May } & 1238 & 1048 \\
\hline \multicolumn{2}{|c|}{$\operatorname{HSD}(P=0.05)$} & 1818 & 1682 \\
\hline \multicolumn{4}{|c|}{$\begin{array}{l}\text { Significant interactions: } \\
\text { - soil x manure }\end{array}$} \\
\hline & Unfert. & 239 & 106 \\
\hline & NPK & 709 & 520 \\
\hline \multirow{2}{*}{$\begin{array}{l}\text { Fine } \\
\text { sand }\end{array}$} & Unfert. & 62 & 19 \\
\hline & NPK & 124 & 33 \\
\hline
\end{tabular}




\section{AGRICULTURAL SCIENCE IN FINLAND}

Kemppainen, E.: Leaching and uptake of nitrogen and phosphorus...

nure was rather small in peat soil but substantially higher in fine sand soil.

In the first experimental year, spreading in December resulted in a lower yield than other treatments. Cow slurry produced the highest yield when spread in May and fox manure when spread in September with Didin. In the second year, there were no significant differences between the spreading treatments but, in the third year, spring application proved to be better than spreading in September with Didin. However, whilst differences between the various treatments with cow slurry were rather small, fox manure clearly produced the best yield when spread in spring.

Comparison with unfertilized lysimeters indicated that very high yield increases were achieved with various fertilization treatments in the first year. In the second and third experimental years, there were substantial residual effects, especially with fox manure.

Table 7. Barley grain yields. Averages for soil types, manure types and spreading times, and figures for control treatments.

\begin{tabular}{|c|c|c|c|c|}
\hline \multirow{2}{*}{\multicolumn{2}{|c|}{ Treatment }} & \multicolumn{3}{|c|}{ Barley grain yield, $\mathrm{kg} / \mathrm{ha}$} \\
\hline & & 1990 & 1991 & 1992 \\
\hline \multirow{3}{*}{\multicolumn{2}{|c|}{$\begin{array}{l}\text { Peat soil } \\
\text { Fine sand soil } \\
\operatorname{HSD}(\mathrm{P}=0.05)\end{array}$}} & 8000 & 6460 & 4950 \\
\hline & & 5750 & 5020 & 4130 \\
\hline & & 1800 & 2350 & 1190 \\
\hline \multirow{3}{*}{\multicolumn{2}{|c|}{$\begin{array}{l}\text { Cow slurry } \\
\text { Fox manure } \\
\text { HSD }(\mathrm{P}=0.05)\end{array}$}} & 4720 & 5230 & 4290 \\
\hline & & 9030 & 6250 & 4800 \\
\hline & & 980 & 1040 & 90 \\
\hline \multirow{5}{*}{\multicolumn{2}{|c|}{$\begin{array}{l}\text { September } \\
\text { September+Didin } \\
\text { December } \\
\text { May } \\
\text { HSD }(P=0.05)\end{array}$}} & 6990 & 5740 & 4430 \\
\hline & & 7770 & 5740 & 4180 \\
\hline & & 5310 & 5830 & 4630 \\
\hline & & 7440 & 5660 & 4930 \\
\hline & & 1130 & 1060 & 600 \\
\hline \multicolumn{4}{|c|}{$\begin{array}{l}\text { Significant interactions: } \\
\text { - soil } \mathrm{x} \text { manure } \\
\text { - manure } \mathrm{x} \text { spreading }\end{array}$} & $\begin{array}{r}* * * \\
*\end{array}$ \\
\hline \multirow{2}{*}{$\begin{array}{l}\text { Peat } \\
"\end{array}$} & Unfert. & 1830 & 5230 & 4090 \\
\hline & NPK & 6970 & 6010 & 6000 \\
\hline \multirow{2}{*}{$\begin{array}{l}\text { Fine } \\
\text { sand }\end{array}$} & Unfert. & 1280 & 4390 & 3930 \\
\hline & NPK & 4680 & 4220 & 3800 \\
\hline
\end{tabular}



Fig. 6. Manure nitrogen in barley yield (grain+straw) and in runoff during the whole experimental period. Comparison of soil and manure types.

\section{Calculated proportion of manure nitrogen in yield and runoff}

Substantially higher amounts of manure nitrogen were found in barley (grain+straw) from peat soil than from fine sand soil (Fig. 6). The amounts of manure nitrogen leached from peat soil were higher, too. Of applied total nitrogen, $41 \%$ was found in the yield and $13 \%$ in runoff from peat soil, and $25 \%$ in the yield and $5 \%$ in runoff from fine sand soil.

Barley treated with fox manure contained much higher amounts of manure nitrogen than that fertilized with cow slurry. However, the amounts of nitrogen leached from fox manure were only similar to or lower than those leached from cow slurry. Of applied total nitrogen, 33\% was found in barley and $5 \%$ in runoff from fox manure, and $34 \%$ in barley and $21 \%$ in runoff from cow slurry.

Recovery of manure nitrogen in barley was highest after application in September with Didin, and lowest after application in December (Fig. 7). Amounts of manure nitrogen leached 


\section{AGRICULTURAL SCIENCE IN FINLAND}

Vol. 4: 363-375.

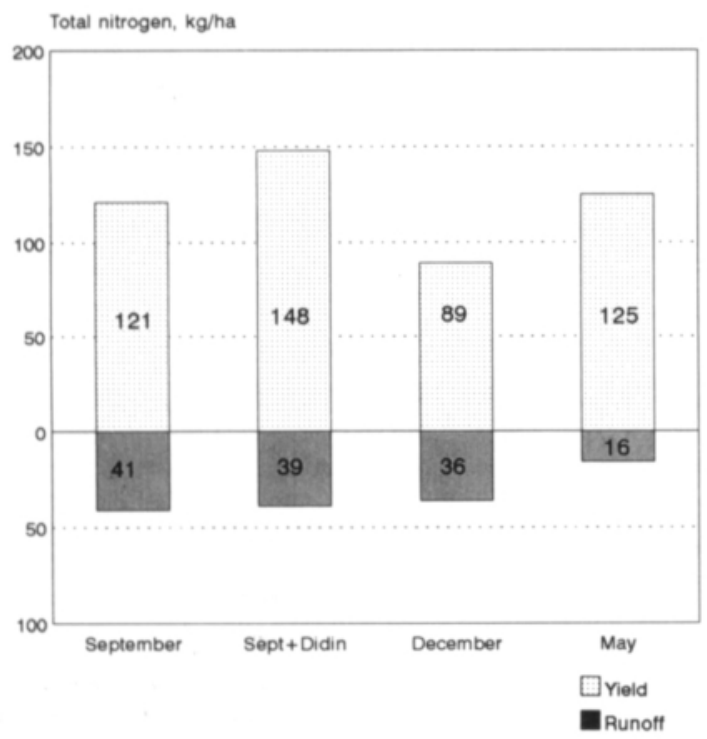

Fig. 7. Manure nitrogen in barley yield (grain+straw) and in runoff during the whole experimental period. Comparison of various spreading treatments.

were of the same order for applications in September, September+Didin and December, but substantially lower after application in May. Of applied total nitrogen, $33 \%, 40 \%, 24 \%$ and $34 \%$ were found in barley after manure application in September, September+Didin, December and May, respectively; the figures for nitrogen found in runoff were $11 \%, 11 \%, 10 \%$ and $4 \%$, respectively.

In peat soil, recovery of fertilizer nitrogen (NPK plots, $85 \mathrm{~kg} \mathrm{~N} / \mathrm{ha}$ ) in barley was about $150 \%$ and in runoff $41 \%$. In fine sand soil, $46 \%$ of nitrogen applied in mineral fertilizer was recovered in barley but none in runoff.

\section{Calculated proportion of manure phosphorus in yield and runoff}

Substantially higher amounts of manure phosphorus were found in barley (grain+straw) from peat soil than from fine sand soil (Fig. 8). Significant amounts of manure phosphorus leached from peat soil but practically none from fine sand

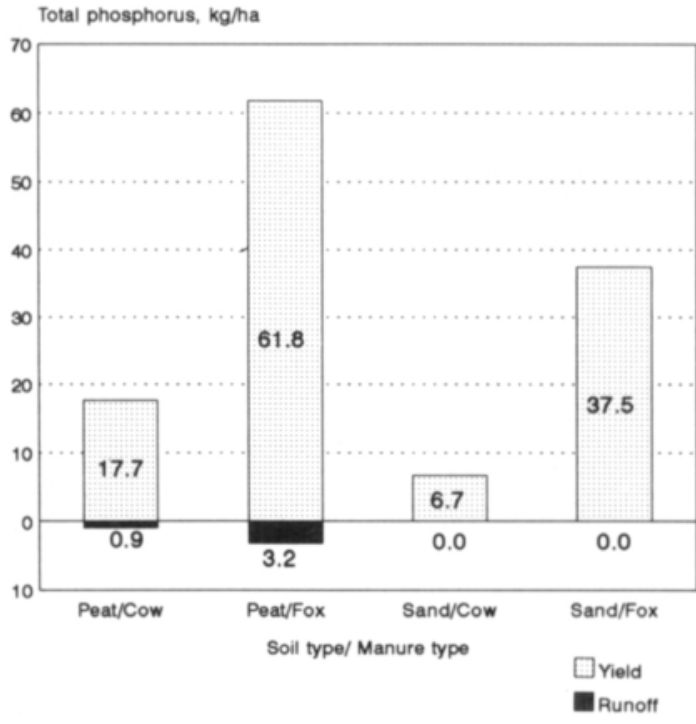

Fig. 8. Manure phosphorus in barley yield (grain+straw) and in runoff during the whole experimental period. Comparison of soil and manure types.

soil. Of applied total phosphorus, $11.1 \%$ was found in barley and $0.6 \%$ in runoff from peat soil; the figures for fine sand soil were $6.2 \%$ and $0 \%$, respectively.

Barley fertilized with fox manure contained much higher amounts of manure phosphorus than that fertilized with cow slurry. In peat soil, a corresponding difference was evident in the leaching of manure phosphorus. Of applied total phosphorus, $50.6 \%$ was found in barley and $2.6 \%$ in runoff from cow slurry in peat soil, and $9.1 \%$ in barley and $0.5 \%$ in runoff from fox manure. In fine sand soil, recovery of manure phosphorus in barley was $19.1 \%$ for cow slurry and $5.5 \%$ for fox manure.

Recovery of manure phosphorus in barley was highest after application in May and lowest after application in December (Fig. 9). The amount of manure phosphorus leached was highest after application in December but the differences between treatments were rather small. Of applied total phosphorus, $8.4 \%, 9.4 \%, 7.3 \%$ and 9.6\% were found in barley after manure application in September, September+Didin, December and May, respectively; the figures for phos- 


\section{AGRICULTURAL SCIENCE IN FINLAND}

Kemppainen, E.: Leaching and uptake of nitrogen and phosphorus...

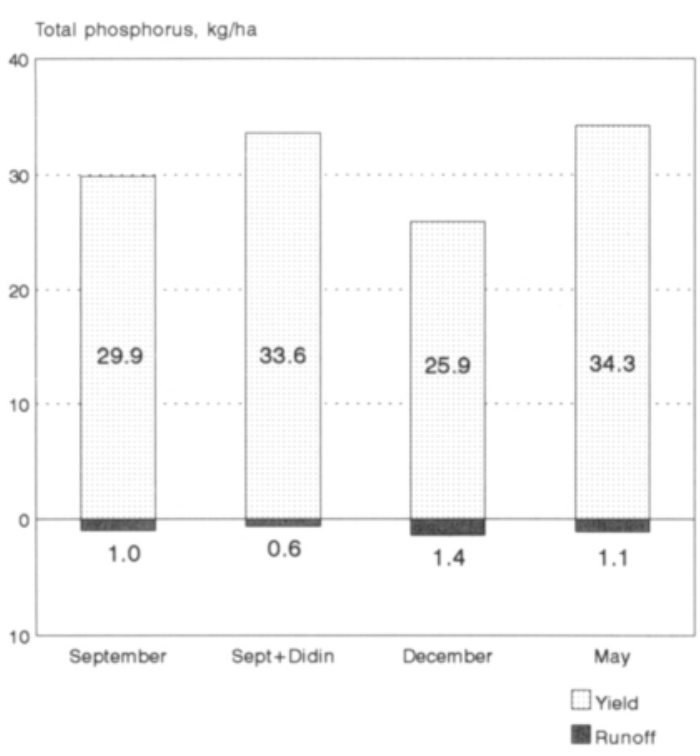

Fig. 9. Manure phosphorus in barley yield (grain+straw) and in runoff during the whole experimental period. Comparison of various spreading treatments.

phorus found in runoff were $0.3 \%, 0.2 \%, 0.4 \%$ and $0.3 \%$, respectively.

Of applied fertilizer phosphorus ( $30 \mathrm{~kg} \mathrm{P} / \mathrm{ha}$ ) in NPK plots, $78.8 \%$ was found in barley and $1.6 \%$ in runoff from peat soil; the figures for fine sand soil were $26.1 \%$ and $0.2 \%$, respectively.

\section{Discussion}

Peat soil was superior to fine sand soil with respect to barley yields and nutrient uptake. However, nutrient leaching from peat soil was also usually higher. As to leaching of total $\mathrm{N}$ and organic $\mathrm{N}$, the difference is explained partly by higher natural leaching and partly by high runoff from peat soil.

High leaching of ammonium nitrogen from peat soil is partly due to significant mineralization of its organic nitrogen and partly to manure ammonia. Owing to the low $\mathrm{pH}$, ammonia oxidizes slowly in peat (Alexander 1991, p. 252).
Considerable leaching of ammonium nitrogen from peat soil was found by Jaakkola and Yläranta (1985).

Substantially more phosphorus leached from peat soil than from fine sand soil, indicating the low capacity of peat soil to bind phosphorus. Marked differences in the phosphorus binding capacity of mineral soils and organogenic soils were noted by Steenvoorden and Oosterom (1981) and Uhlen and Österud (1992). Very high phosphorus losses from manure-treated peat soils were demonstrated by Scheffer et al. (1981) and Bartels and Scheffer (1987).

A conspicuous feature of this study was the high $\mathrm{P}$ loss during the two latter leaching periods, especially from fox manure in peat soil. It seems that the leaching of phosphorus began about two years after manure application. It is probable that significant $P$ losses will occur after the end of the experiment and the differences between various treatments will still increase.

Fox manure was superior to cow slurry with respect to barley yields and nutrient uptake. However, the leaching of total nitrogen from fox manure was more or less the same as that from cow slurry even though the amount of total nitrogen supplied in fox manure was 3.4 -fold that in cow slurry. The luxuriant vegetation produced by fox manure used much water and thus reduced runoff more effectively than cow slurry. Ample fertilization and subsequent luxuriant growth have been shown to reduce runoff in other studies, too (Eder 1985, Jaakkola and Yläranta 1985, Stauffer and Enggist 1990).

The phenomenon described above, that is, a higher nutrient amount increasing yield and nutrient uptake but not nutrient leaching, is possible only when other growth factors do not limit plant growth. Growing conditions seem to have been surprisingly good in the lysimeters because barley was able to utilize the high level of nitrogen supplied by fox manure. However, these results are not comparable to those at field scale, where leaching becomes important at substantially lower nitrogen levels.

Nitrogen uptake by barley was highest after treatment with manure with Didin in September, 


\section{AGRICULTURAL SCIENCE IN FINLAND}

Vol. 4: 363-375.

and lowest in treatment with manure in December. The differences between treatments are mainly ascribed to differences in ammonia volatilization. December was an especially poor spreading time because manure could not be incorporated into the frozen soil. September was better because the manure was mixed into the soil shortly after spreading. In May, manure was left on the soil surface for three days before it was incorporated; the delay is reflected in the $\mathrm{N}$ recovery data.

The effect of spreading time on the leaching of total nitrogen, nitrate nitrogen, ammonium nitrogen and organic nitrogen was clearly demonstrated. Nitrogen leaching was lowest from the spring application and highest from applications in September. These results are consistent with those reported in the literature (Vetter and Steffens 1977, 1981, Brink and Jernlås 1982, Dijk 1985, Ivarsson and Brink 1985, Brink 1987, Görlitz 1989, Torstensson 1992).

Didin did not have a significant effect on nitrogen leaching. This was surprising because several studies have shown that Didin is very effective at saving nitrogen (Amberger 1989, Asmus 1989, Görlitz 1989). According to Amberger (1991) Didin may have a poor effect if manure is spread too early. Didin then decomposes and loses its effect before winter. In this study, slurry treated with Didin was spread in late September, which, according to Kemppainen (1989a), is usually a favourable time for Didin in Finland. However, after application, the soil temperature fell from about $11^{\circ} \mathrm{C}$ to $3-4^{\circ} \mathrm{C}$ in a few days and remained very low until the soil froze at the end of November. It is thus very unlikely that Didin lost its effect through decomposition during the autumn. It is more likely that the soil temperature was too low for significant nitrification to occur and so Didin had only a minor effect (Maidl and Fischbeck 1989). This conclusion is supported by the fact that, during the first leaching period, leaching of nitrate nitrogen from lysimeters fertilized with livestock manure was rather small. Didin, however, seemed to have a positive effect on the recovery of nitrogen in barley.

\section{References}

Alexander, M. 1991. Introduction to Soil Microbiology. 2nd ed. Malabar, Florida. 467 p.

Amberger, A. 1981. Dicyandiamid ("Didin") als Nitrifikationshemmstoff. Bayerisches Landwirtschaftliches Jahrbuch 7/81: 845-853.

- 1989. Research on dicyandiamide as a nitrification inhibitor and future outlook. Communications in Soil Science and Plant Analysis 20: 1933-1955.

- 1991. Slurry fertilization with the aim of low nitrate leaching. Recent Developments in Animal Waste Utilization. FAO. REUR Technical Series 17: 223-225.

Asmus, F. 1989. Untersuchungen zur Reduzierung der $\mathrm{N}$-Verlagerung nach Gülledüngung in Sand-Rosterde. Archiv für Acker- und Pflanzenbau und Bodenkunde 33: 573-579.

Bartels, R. \& Scheffer, B. 1987. Limitations for slurry application to peat grassland. Animal Manure on Grassland and Fodder Crops. Fertilizer or Waste? p. 365-367. Dordrecht.

Brink, N. 1987. Kvăve och fosfor frân stallgŏdslad åker. Ekohydrologi 24/87: 38-39.

-, Gustafson, A. \& Persson, G. 1979. Förluster av kvăve, fosfor och kalium från áker. Ekohydrologi 4/79: 7-57.

- \& Jernlás, R. 1982. Utlakning vid spridning höst och vår av flytgödsel. Ekohydrologi 12/82: 3-14.

Dijk, T. A. van. 1985. De uitspoeling van mineralen op bouwland waaraan jaarlijks drijfmest wordt toegediend. Summary: Leaching of plant nutrients from arable land as affected by annual applications of cattle slurry. Instituut voor Bodemvruchtbaarheid. Rapport 2/85. p. 1-61. Eder, G. 1985. Der Einfluss steigender Güllegaben auf den Boden, den Pflanzenertrag, die Futterqualität und das Sickerwasser. Veröffentlichungen der Bundesanstalt für alpenländische Landwirtschaft, Gumpenstein. Heft 3: $1-19$.

Görlitz, H. 1989. Verringerung der N-Verlagerung im Boden nach Gülledüngung durch Einsatz von Nitrifikationsinhibitoren - Ergebnisse aus Lysimeteruntersuchungen. Archiv für Acker- und Pflanzenbau und Bodenkunde 33: 567-572.

- 1990. Gülleeinsatz mit Nitrifikationsinhibitoren im Herbst zu Wintergetreide. Agrobiological Research 43, 3: 253259. 


\section{AGRICULTURAL SCIENCE IN FINLAND}

Kemppainen, E.: Leaching and uptake of nitrogen and phosphorus...

-, Asmus, F., Völker, U., Benthin, K. \& Müller, H. 1988. Verminderung der Stickstoffauswaschung nach Gülledüngung durch Einsatz von Nitrifikationsinhibitoren und Kombination mit Strohdūngung. Zentralblatt für Mikrobiologie 143: 323-330.

Herrmann, V., Görlitz, H. \& Asmus, F. 1983. Lysimeteruntersuchungen zur Năhrstoffverlagerung nach Gülledūngung in einer Sand-Rosterde - Phosphor, Kalium und Magnesium. Archiv für Acker- und Pflanzenbau und Bodenkunde 27: 687-692.

Ivarsson, K. \& Brink, N. 1985. Utlakning frản en grovmojord i Halland. Ekohydrologi 20/85: 13-25.

Jaakkola, A. \& Yläranta, T. 1985. Typen huuhtoutuminen ja hyvăksikäyttö lysimetrikokeessa. Summary: Leaching of nitrogen and its utilization by plants in lysimeters. SITRA. Nitrogen project. Julkaisu 22: 1-38.

Kähäri, J. \& Nissinen, H. 1978. The mineral element contents of timothy (Phleum pratense) in Finland. I. Acta Agriculturae Scandinavica, Supplement 20: 26-39.

Kemppainen, E. 1984. Karjanlannan ravinnepitoisuus ja syyt sen vaihteluun. Summary: The nutrient content of livestock manure and the causes of its variation. SITRA. Nitrogen project. Julkaisu 11: 1-80.

- 1989a. Effect of Didin (Dicyandiamide) on the fertilizer value of cow slurry for barley. Annales Agriculturae Fenniae 28: 133-150.

- 1989b. Nutrient content and fertilizer value of livestock manure with special reference to cow manure. Annales Agriculturae Fenniae 28: 163-284.

Kjellerup, V. 1986. Nitrogen effect of slurry mixed with nitrification inhibitors: field experiments. Efficient Land Use of Sludge and Manure. p. 2-6. London.

MaidI, F. X. \& Fischbeck, G. 1989. Effects of Long-term Applications of Slurry on Soil Nitrogen Mineralization. Journal of Agronomy and Crop Science 162: 310-319.

Meissner, R., Kramer, D., Taeger, H. \& Schonert, P. 1991. Lysimeterversuchsergebnisse über die Wirkung der Nitrifizide "Dicyandiamid" (DCD) und "1-Carbamoyl-3(5)methylpyrazol" (CMP). Archiv für Acker- und Pflanzenbau und Bodenkunde 35: 411-423.

Melanen, M., Jaakkola, A., Melkas, M., Ahtiainen, M. \& Matinvesi, J. 1985. Leaching resulting from land application of sewage sludge and slurry. Vesientutkimuslaitoksen julkaisuja 61. $124 \mathrm{p}$.

Niinioja, R. 1993. Lietelannan levitys ja ravinteiden huuhtoutuminen. Summary: Leaching of nutrients from land application of slurry. Publications of the Water and Environment Administration. A 150: 1-87.
Nilsson, L. G. 1991. Nitrifikationshämmare - flytgödsel. Sveriges Lantbruksuniversitet. Institutionen för Markvetenskap. Rapport 181: 1-28.

Pain, B. F., Thompson, R. B., De la Lande Cremer, L. C. N. \& Ten Holte, L. 1987. The use of additives in livestock slurries to improve their flow properties, conserve nitrogen and reduce odours. Animal Manure on Grassland and Fidder Crops. Fertilizer or Waste? p. 229-246. Dordrecht.

Pedersen, J. B. 1991. Forurening fra pelsdyrfarme. Miljöstyrelsen (Danmark). Miljöprojekt nr. 163: 1-96.

SAS Institute 1985. SAS User's Guide: Statistics, Version 5 Edition. Gary, NC. 956 p.

Scheffer, B. von, Kuntze, H. \& Bartels, R. 1981. Zum Phosphataustrag aus mit Gülle gedüngtem Hochmoorboden. Landwirtschafliche Forschung, Sonderheft 40: 288-296.

Stauffer, W. \& Enggist, A. 1990. Einfluss von Gülleausbringtermin, Kultur und Wiesenumbruch auf die Nitratauswaschung in einem Lysimeterversuch. Landwirtschaft Schweiz 3, 7: 373-379.

Steenvoorden, J. H. A. M. \& Oosterom, H. P. 1981. Natural and artificial sources of nitrogen and phosphate pollution of surface waters in the Netherlands. Nitrogen Losses and Surface Run-off from Landspreading of Manures. p. 307-333. The Hague.

Torstensson, G. 1992. Kvăveutlakning i storruteförsōk med stallgődsel. Hudyrgődning, Resurse - Miljō. NJF Utredninger-Rapporter 74: 97-101.

Tveitnes, S. \& Halland, A.. 1989. Influence of the nitrification inhibitor Dicyandiamide (DCD) on the nitrogen efficiency of cattle slurry. Norwegian Journal of Agricultural Sciences 3: 343-350.

Uhlen, G. \& Österud, J. G. 1992. Nitrogen, fosfor og kalium i gröftevannspröver fra dyrket mark. Norsk Landbruksforskning 6: 61-72.

Vetter, H. \& Steffens, G. 1977. Der Einfluss gestaffelter Güllemengen und verschiedener Düngungszeitpunkte auf die Năhrstoffverlagerung in tiefere Bodenschichten und in das Wasser. Landwirtschafliche Forschung, Sonderheft 34: 238-246.

- \& Steffens, G. 1981. Năhrstoffverlagerung und Năhrstoffeintrag in das oberflachennahe Grundwasser nach Gülledüngung. Zeitschrift für Kulturtechnik und Flurbereinigung 22: 159-172.

Vuorinen, J. \& Mäkitie, O. 1955. The method of soil testing in use in Finland. Agrogeological Publications 63: 144. 
Vol. 4: 363-375.

\title{
SELOSTUS
}

\section{Naudan lietelannan ja ketun lannan typen ja fosforin huuhtoutuminen ja hyväksikäyttö lysimetrikokeessa}

\author{
Erkki Kemppainen \\ Maatalouden tutkimuskeskus
}

Lysimetrikokeessa tutkittiin maalajin, levitysajan sekä nitrifikaatioinhibiittorin (Didin) vaikutusta naudan lietelannan ja ketun lannan typen ja fosforin huuhtoutumiseen ja hyväksikäyttöön.

Valunta ja kokonaistypen huuhtoutuminen turvemaasta olivat noin kaksinkertaisia hietaan verrattuna. Nitraattitypen huuhtoutumisessa ei ollut merkittävää eroa, mutta ammoniumtyppeä turvemaasta huuhtoutui 50-kertainen määrä ja orgaanista typpeä 3-kertainen määrä hietaan verrattuna. Turvemaasta huuhtoutui myös kokonaisfosforia 23-kertainen määrä ja liukoista fosforia 39-kertainen määrä hietaan verrattuna.

Naudan lietelannasta ja ketun lannasta huuhtoutui suunnilleen yhtä paljon typpeä. Typpeä huuhtou- tui vähiten toukokuussa levitetystä lannasta. Didin ei vähentänyt typen huuhtoutumista merkitsevästi. Ketun lannasta huuhtoutui turvemaalla selvästi enemmän fosforia kuin naudan lietelannasta. Lannan levitysaika ei vaikuttanut fosforin huuhtoutumiseen.

Turvemaa tuotti huomattavasti suurempia ohrasatoja kuin hieta. Ketun lanta oli selvästi naudan lietelantaa tehokkaampaa lannoitetta. Ensimmäisenä koevuonna lannan levitys joulukuussa vähensi merkitsevästi sen lannoitusvaikutusta muihin levitysaikoihin verrattuna. Ohran jyvä- ja olkisadon perusteella laskettuna lannan kokonaistypen näennäinen hyväksikäyttö oli $24-41 \%$ ja lannan fosforin hyväksikäyttö 6-51\%. Lannan kokonaistypestä huuhtoutui 4-21\% ja fosforista $0-2,6 \%$. 